\title{
Familial digital arthropathy-brachydactyly
}

INSERM

\section{Source}

INSERM. (1999). Orphanet: an online rare disease and orphan drug data base. Familial digital arthropathy-brachydactyly. ORPHA:85169

Familial digital arthropathy-brachydactyly is characterised by the association of arthropathy of interphalangeal, metacarpophalangeal and metatarsophalangeal joints with brachydactyly of the middle and distal phalanges. It has been described in numerous members from five generations of one large family. Inheritance is autosomal dominant. 